\title{
EUHTE3E
}

2018, бр. 13, стр. 1 -26

UDK 371.322 .5

Оригинални научни чланак

doi:10.5937/sinteze7-16996

37.036-057.874

\section{FORMS OF PUPILS` FREE TIME ACTIVITIES IN SERVICE OF FOSTERING THEIR AESTHETHIC TASTE}

\author{
Ljiljana Lj. Mitrovićl, Danijela S. Panić' ${ }^{2}$ Dragana D. Lazić ${ }^{3}$
}

Abstract: This paper deals with the free time activities of pupils, that is, the organized forms of educational work that is realized through the work of sections that are in the service of fostering aesthetic taste. The paper examines the pupils' opinion on participation in the sections. The sample of this study consists of 140 pupils from four elementary schools. The research was carried out using the method of data collection and survey technique and the questionnaire was used as an instrument. The results of the research show that pupils are interested in working in free time activities, that they are not overburdened by the work in them and that they have a positive opinion about cultural and artistic events. Also, the results show the link between pupils' school achievement and participation in free time activities. The work brings useful knowledge about pupils' interests.

Key word: free time activities, sections, elementary school, aesthetic taste, cultural and artistic events.

\section{INTRODUCTION}

Free time pupils activities form an integral part of the structure of educational work and as such they draw attention to the analysis of their place and role in that structure, as well as in the achievement of educational goals. In addition to the application of commonly known means and forms of work, it is necessary to constantly direct pupils to the acquisition of aesthetic values. It is necessary for the pupils to develop the need for beauty and art. Aesthetic development of the personality enriches and expands aesthetic needs and

1 mitroviclj@spinter.net, Primary school „Vuk Karadžić“, Zabrđe, Republic of Srpska, Bosnia and Herzegovina

${ }^{2}$ simeunovic.danijela@gmail.com, Primary school „Knez Ivo od Semberije“, Bijeljina, Republic of Srpska, Bosnia and Herzegovina

${ }^{3}$ draganaldj@gmail.com, Primary school „Knez Ivo od Semberije“, Bijeljina, Republic of Srpska, Bosnia and Herzegovina 
aesthetic interest, which focus pupils on discovering, experiencing and creating something beautiful in life and in all branches of art. The remedy for preventing the superficial experience in childhood is in developing a sense of beauty and critical thinking, as well as in the creative use of all forms of expression - in word, movement, music, colour and various forms. The child should be familiarized with as many artistic activities as possible in which he can actively participate and acquire experiences about himself and the world he lives in.

Through artistic activities, the pupil will be able to establish an entire network of inner and outer relationships and relationships within himself and with others, to gain awareness of oneself, about his time and other people with whom he builds his social reality, and will be able to introduce himself as creator, an active participant who, through his actions and behaviour, can build and change his world. Aesthetic interests and needs entice pupils to be active, seek to be satisfied and become a powerful motive for the pupil's deeper and more complete involvement in the area of the beautiful. As a result and the crown of work on the development of aesthetic culture, aesthetic taste is formed. Free activities play an important educational role in the formation of aesthetic taste.

This research will find out pupils' interest in participating in free time activities, establish whethe pupils are overburdened with work in free time activities, as well as their opinion on cultural and artistic events organized in schools.

By examining pupils' opinions and analyzing the answers received, we will be able to conclude whether pupils are sufficiently interested in participating in free time activities and whether there is a difference in interest in terms of gender, school age and student achievement. Also, it will be seen whether there is a problem of overloading pupils with participation in free activities and whether it can be linked to pupils' gender, school age and school success. Examining pupils' opinions on cultural and artistic events can contribute to their better organization and preparation for further work. It will be appreciated whether the contents that are performed on them bear the educational effect and whether they enhance the aesthetic taste of the pupils. By confirming or refuting the hypothesis and using the variables in this study, results are expected to confirm the positive impact of free time activities on pupils' school success and fostering aesthetic taste, and teachers will be able to use the results in further work.

\section{DEFINING FREE ACTIVITIES}

Primary school, in its realization of its educational goals, uses a variety of forms of activity, among which are free activities. Free time activities represent a special form of educational work with pupils organized by the school outside the classroom, in pupil's free time. These are the collective activities of students based on the principles of free choice, independence and self-government, in which pupils satisfy their interests, develop abilities, express their creativity. Together with the teaching and other forms of educational activities, school contribute to a more 
successful realization of the tasks of education in the formation of the versatile creative personality of the pupils (Pedagogical Encyclopedia 2, 1989).

Free time activities, in addition to teaching, significantly contribute to the improvement of the quality of the teaching process with their structure and organization. The school, as an institution of importance for the social environment in which it is located, should provide every young man with a starting basis for upbringing and education. It achieves its function, first of all, by teaching, which is the most dominant form of pedagogical work, but besides teaching, there are certainly free activities. Free activities in the elementary school include all forms of educational work organized by the school, together with the local social environment, in order to create opportunities for the pupils to express, satisfy and further develop their social activities, preferences, abilities and interests (Pjurkovska-Petrović \& Ševkušić, 1997: 351). These activities, as their name suggests, take place in the pupil's free time, that is, outside the classroom. This fact alone contributes to the greater freedom of expression of students because there is no classical assessment, expression of their interests, desires and preferences, everything that may be somewhat denied to them due to various factors: lack of time, poor motivation of teachers, but also because of financial abilities and abilities of the staff to pay equal attention to the interests of each pupil individually at regular times.

Educational activities that are organized by pupils in the school or outside, in cooperation with teachers and which serve for the more versatile development of pupils (performed mainly by them alone), are called free time activities (Grandić \& Letić, 2008: 120). Teaching is managed by a teacher, while with free activities this is not the case, because they are usually performed by pupils. However, such free time activities do not mean that teachers are only passive observers who do not care about the events during this work. Teachers are active participants in free time activities, but they are equal with students, they encourage, motivate, direct, work together with pupils, but not as a subject-object situations, which is characteristic for the traditional form of teaching.

Boško Cvetković gave a definition of free time that encompasses forms of educational work that meet specific interests and special preferences of pupils, contributing to the expansion, strengthening and deepening of these interests and preferences, and extending and deepening these interests and preferences, as well as expanding and the deepening of knowledge that is of personal significance for pupil, the development of pupil's skills and abilities, the manifestation and fostering of their creativity, the strengthening of their self-confidence, the development of a sense of cooperation (with each other and with adults) and comradeship, introducing values in their own lives and thwarting undesirable behaviour (Cvetković, 1999: 400). In his opinion, they make the life of the pupils fuller, richer, more beautiful, more thoughtful and more pleasant. 


\section{CLASSIFICATION OF FREE ACTIVITES}

Activities that take place in free time depend on a large number of factors, so there are more classifications. Numerous authors have given their views on the classification of free time activities.

Drago Branković (2003) states that the most acceptable is the classification that starts from the occupation of an individual. According to this criterion, the following activities can be distinguished:

1. physical and recreational activities (interest for walking, excursions, trips, sports activities, etc.),

2. altruistic-pedagogical activities (humanitarian and educational activities),

3. cultural-aesthetic activities (observing, experiencing and creating cultural goods in the fields of music, literature, film, theatre and fine arts);

4. Manual-work activities (predominantly work activities and work creativity as a hobby) services),

5. Religious activities (visits to religious sites, religious meetings, religious

6. hedonistic-hazardous activities (hazardous games, adventures and similar),

7. Educational activities (activities for acquiring knowledge, skills and habits, and developing certain individual abilities).

Pursuant to the Law on Primary Education and Upbringing and the Law on the Government of Republika Srpska (Official Gazette of the Republic of Srpska, No. 51/11), Pedagogical Standards and Norms for Primary Education are adopted. Article 17 of the Standard lists areas of extracurricular activities that include free time activities:

- culture and art (drama, choir, music, art, literary, recitation, folklore, ballet section);

- economic activity - cooperatives (librarian, commercial, ratar, vegetable, poultry, vineyard, fruit, cattle breeding, bee-keeping, small animal production);

- technique and technology (sections and clubs of young technicians, radio amateurs, photo amateurs of innovators, modelers, transporters, cybernetics, computer section, etc.);

- supplementing and expanding knowledge - creativity (sections: mathematicians, physicists, biologists, chemists, historians, geographers, foreign languages, linguists, circles and editors for other subjects and areas);

- physical and health education (sports, athletics, gymnastics, rhythmic gymnastics, judo, karate, sports shooting, skiing, swimming); - preserving the natural environment (sections and clubs of young naturalists, scouts, mountaineers, mountains, lovers of healthy human environment).

It is desirable that all groups of free time activities are included in the life of pupils of elementary school age, since this period is very important for further growth and personality development. These activities interrelate with each other, they are interlinked and it can only be discussed about approaching or increasing pupils' interest in a particular group of activities, but not about their neglect. 
In the literature, the most acceptable distribution of free time activities in the areas in which they are performed is that given by Radenko Krulj, Sait Kačapor and Radivoje Kulić (2002). According to this criterion, all free activities can be grouped into the following groups:
1. scientific-subject,
2. technical,
3. economic-production,
4. cultural and artistic,
5. sports and entertainment (Grandić \& Letić, 2008)

In addition to all the positive characteristics that involve free time activities, the issues of pupils' burden within sections as well as the pupils' success in the work of the free activity sections are also important. As for the first issue, overburdened with the sections are most often gifted and ambitious students who often accept too many or too many inappropriate tasks, especially in certain competitions that can be at school level, municipality level, regional level and broader ones. The pupils are particularly burdened at that time because they are under pressure: a lot is expected from them, and most often it is not just about the prestige of pupils, but also of the entire school.

The question of pupils' success in the work of the sections is also an important problem to be mentioned. Although, in principle, "success succeeds" with all pupils, it still encourages some to continue, while others stop in their complacency over the victory, as the failure discourages one and encourages the other to increase their efforts.

This topic shows the connection between teaching and free time activities; the success that students achieve in free time activities encourages further activity, which contributes to better success in the field of teaching.

One of the weaknesses of free time activities is, for example, that they become compulsory for pupils, too much attention is paid to preparation for the competition at the expense of the teaching, etc. Another weakness may be that teachers do not take the age of the pupils into account properly, treating pupils of various ages in the same manner. Teachers should gradually introduce pupils to free activities by enabling pupils of the second grade to get to know some of their types, pupils of the third grade to acquire impressions about their abilities, assess their wishes, form some activities on their own choices and pupils of the fourth grade, in addition to meeting new activities, to critically evaluate their abilities. This concept is based on contemporary psychological learning (Piaget, Kolberg, B. Popović et al.) by which children are inherited with heteronomous morality, which is reflected in attachment, obedience to the teacher, to their ninth that is tenth year and they can not be given the organization of work in the collectives. Strong motivation for self-organization and the formation of one's own activity occurs only around eleven years. Thus, only fifth-grade pupils choose to participate in permanent stakeholders, and after they have been prepared in the previous grades. 
All these free time activities affect certain aspects of pupils' development. Each of them is aimed at developing certain abilities and qualities in children with voluntary organization and on the initiative of the pupils themselves whose needs and possibilities are put to the forefront. Of course, one should not ignore and omit the role of a teacher, who, as an expert, is required to direct students to the correct performance of the activity, in order to extract the maximum from them important for their development. Also, as the name implies, maintenance time of free activities is out of school. It should not be intertwined with the time provided for teaching with free time activities, as then there will be no time for educational activity. Although each of them has an impact on individual aspect of personality development (developing scientific and technical potentials, production activities, developing a sense of culture and art, and working on them, as well as for proper physical development), it is impossible and unreasonable to deal with all free activities. Grandić emphasizes that it is best for students to participate in one or two free activities so that they do not get scattered in various directions, that is, from the one or two activities that they are dealing with, they draw the maximum for their development.

\section{OVERVIEW OF THE PAST RESEARCHE}

An important piece of research dealing with the structure of free activities from the fifth to the eighth grade, is the research by Jovan Bećar (1986). It is in the area of the Educational and Pedagogical Institute in Subotica on a sample of 24 elementary schools. As a data source, the researcher used annual school work programs and reports on the results of educational work. According to this research, the most important activities are the ones related to teaching subjects and areas $(37,34 \%)$, then sports activities $(25,74 \%)$, while cultural and artistic activities, which include dramatic, literary, puppet, folklore and other sections, are slightly less represented (19.83\%). Production and technical activities are the least represented (17.09\%).

It is interesting to explore the problem of how free and active the pupils' free time activities are (Đorđević, 1985). The research has shown that a large percentage of pupils is included in non-teaching sections out of their own preferences or at the request of teachers. Another problem is that pupils become overburdened by activities, since of the 300 respondents 88 are in three, and 13 in four sections. Particular attention is paid to the fact that $14 \%$ of pupils is not in any section, because teachers consider them poor students and do not see the need for their engagement in activities.

Radomir Babin (1986) organized a small study among pupils about the thematic-idea profile of the program, which is performed at school events. A total of 107 pupils of the third grade of secondary school were interviewed, who answered two questions: what do they think about cultural and artistic events and how they evaluate the contents of these events? $38.93 \%$ of respondents show positive attitude on the first question, while $61.07 \%$ think negatively about them. The second question is the ratio of $29.6 \%$ positive to $70.4 \%$ of the negative 
grades on the content that is performed at school events. From the answers to these two questions, the author concluded that excessive repetition of identical content, pre-medicalization of events, especially if the corresponding performance level is not achieved, result in negative effects.

These studies show that there is a certain amount of research on the free activities of pupils, but they also tell us that they should nevertheless pay more attention to these forms of activity and work on their promotion.

\section{RESEARCH METHODOLOGY}

The problem of this research is free time activities in the service of fostering aesthetic taste. The fact is that free time activities are an essential component of aesthetic education, that is, the entire educational work, which motivated this research. Pupils should be interested in free time activities, but they should not be overburdened, and to show their abilities by participating in cultural and artistic events.

The following questions are raised: Are pupils interested in participating in free time activities, are they optimally burdened, and what is their opinion on cultural and artistic events, and how are they affected by gender, age and school success?

The subject of the research is to examine the opinion of primary school pupils about participation in free activities that are in the service of fostering aesthetic taste.

The research also determined the dependent and independent variable. The dependent variable consists of the attitudes and opinions of students about free time activities in the service of fostering aesthetic taste, and the independent variable consists of the gender of the pupil, school age and school success.

The aim of the research is to determine the opinion of primary school pupils about free time activities that are in the service of fostering aesthetic taste with regard to their socio-pedagogical characteristics, that is, gender, school age and school success.

The following tasks arise from this defined goal of the research:

1. To determine the pupils' interest in participating in free time activities that are in the service of fostering aesthetic taste in terms of gender, school age and school success of pupils,

2. In relation to school success, gender and school age of the pupil, it should be examined the pupil's attitudes about their efforts and workload in free time activities that are in the service of fostering its aesthetic taste,

3. Examine pupils' opinions on cultural and artistic events.

For the purposes of this research, the main hypothesis has been defined, as well as three auxiliary hypotheses, which will serve for a more detailed explanation of the main hypothesis.

Main hypothesis: 
- It is assumed that pupils' participation in free time activities organized in elementary schools promotes fostering the aesthetic taste of pupils and that there is a link between pupils' participation in free activities and pupils' school achievement.

Auxiliary hypotheses:

- It is assumed that pupils are interested in participating in free time activities and that there is a statistically significant difference in relation to their gender, school age and school success.

- It is expected that there is a difference in the efforts and burdens of pupils in working in free time activities that are in the service of fostering aesthetic taste, depending on their school success, gender and school age.

- It is assumed that students have a positive opinion about cultural and artistic events that contribute to fostering their aesthetic taste.

The method of data collection was used as a supplement to the basic method for the purpose of research, that is, the analyses of the relevant facts and syntheses of the theoretical facts relevant to the research problem. The research procedure was selected considering the essence of the research, because it is suitable for getting to know the characteristics of pedagogical phenomena based on the opinions and attitudes of the respondents. A descriptive method was also used.

Research techniques are content analysis and surveys.

The instrument to be used in research is a questionnaire for pupils, which will be used to examine the opinions and attitudes of pupils about participation, interest and burden of work in free activities that serve to foster aesthetic taste, as well as their opinions on cultural and artistic events.

A questionnaire of pupils' free time activities compiled for the purpose of this research consists of instructions and 15 questions.

The population of this research consists of pupils of elementary school (fifth grade) and subject classes (sixth, seventh and eighth grade) of elementary schools in the area of Bijeljina city and Brčko municipality in the school year 2015/2016.

The minimum sample size for 545 students with a confidence level of $99 \%$ ( $1 \%$ of error options) and a confidence interval of $+/-10 \%$ requires 140 respondents.

Table 1: Structure of the sample by gender

\begin{tabular}{lll}
\hline Gender & f & $\%$ \\
\hline$M$ & 51 & 36,43 \\
$F$ & 89 & 63,57 \\
\hline Total: & 140 & 100,0 \\
\hline
\end{tabular}

Table 2: Sample structure by school age

\begin{tabular}{lll}
\hline School age & $\mathrm{f}$ & $\%$ \\
\hline Clasroom teaching & 70 & 50,0 \\
Subject teaching & 70 & 50,0 \\
\hline Total: & 140 & 100,0 \\
\hline
\end{tabular}


Table 3: Structure of the sample by academic success

\begin{tabular}{lll}
\hline School success & $\mathrm{f}$ & $\%$ \\
\hline Excellent (5) & 102 & 72,86 \\
Very good (4) & 31 & 22,14 \\
Good (3) & 7 & 5,0 \\
Enough (2) & 0 & 0,0 \\
\hline Total: & 140 & 100,0 \\
\hline
\end{tabular}

Given the variables, the gender and school success of the pupils, it is the uneven structure of the samples, whereas considering the school age variable it is the uniform structure of the sample.

Statistical data were obtained by processing the data collected by the questionnaire. The percentages, arithmetic meanings, contour tables and the hi-square test are calculated.

This empirical non-experimental study was carried out in June, 2016 at the end of the school year. During the research, pupils were interested and open to cooperation. The interview lasted between 15 and 20 minutes in all departments.

\section{THE ANALYSIS AND INTERPRETATION OF THE RESEARCH}

In this chapter, the importance of research in the field of free time activities related to elementary school is emphasized from various aspects. Through the analysis and interpretation of the research, results will be provided, which will give answers to the hypotheses.

Pupils' interest in participating in free time activities

Pupils' interest in participating in free activities is an essential prerequisite for successful work in free activities, as well as for developing aesthetic taste in students, and therefore, pupils' interest is important for research. The following table shows data on pupil participation in various free time activities in which they actively participate. Pupils could mark more responses.

Table 4: Participation of students in free activities

\begin{tabular}{lll}
\hline Section & Number of students & $\%$ \\
\hline Drama section & 25 & $11,85 \%$ \\
Recitation section & 6 & $2,84 \%$ \\
Drama-recitation section & 61 & $28,91 \%$ \\
Journalistic section & 0 & $0,0 \%$ \\
Literary section & 6 & $2,84 \%$ \\
The puppet section & 0 & $0,0 \%$ \\
Choral singing section & 56 & $26,54 \%$ \\
Orchestra section & 13 & $6,16 \%$ \\
Folklore section & 40 & $18,96 \%$ \\
Art section & 4 & $1,89 \%$ \\
Photo section & 0 & $0,0 \%$ \\
\hline Total: & $211 *$ & \\
\hline
\end{tabular}


Note: $* 53$ students participate in the work of two or more sections

According to the data presented in Table 4, we see that the largest number of pupils participate in the drama-recitation section (28.9\%), then choir (26.5\%), etc. Schools covered by this research do not organize the work of journalistic, puppet and photo sections.

36 pupils participate in two sections, 16 pupils in three and one pupil participates in four sections. The pupil, who participates in four sections is excellent one, female and older school age (subject teaching). This pupil attends drama, recitation, choir and folklore section. The drama and choir section are attended by 13 pupils, four boys and nine girls, 11 excellent and two very good pupils, 12 younger and one older school age. Drama and literary section are attended by three students, a boy, excellent success and of an older school age. From the above examples, we can conclude that only pupils with a better academic achievement participate in more than one section, that is, participation in free time activities depends on school success. There is a difference in gender among the pupils studied. Girls participate more in working in free time activites $(68.25 \%)$ than boys $(31.75 \%)$.

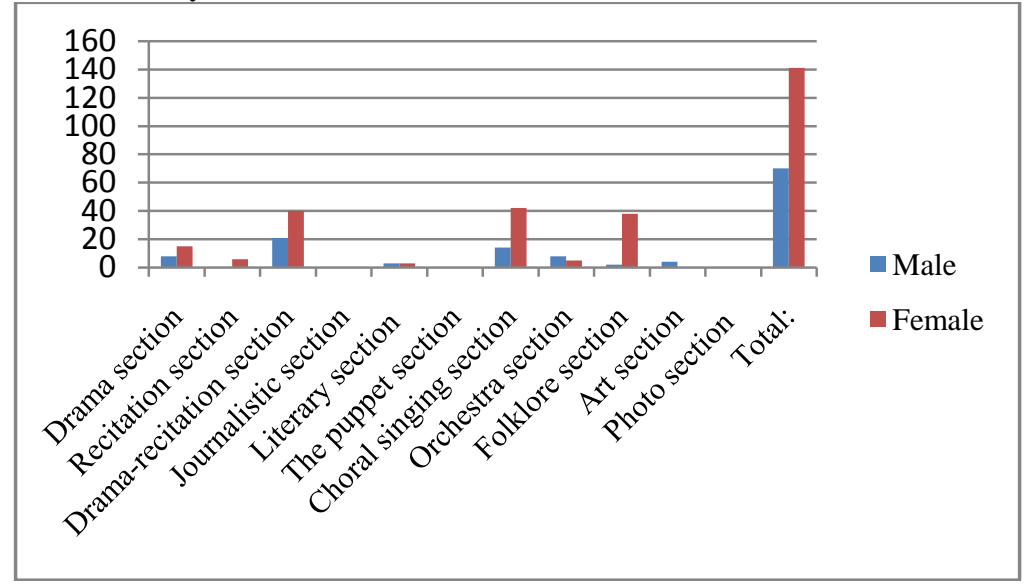

Chart 1: Participation of pupils in free activities in relation to gender

The structure of the answer to the question about pupils awareness about free time activities organized at school is shown in Table 5.

Table 5: Informing pupils about free school activities

\begin{tabular}{lll}
\hline Claim & $\mathrm{f}$ & $\%$ \\
\hline Yes & 119 & $85 \%$ \\
No & 8 & $5,71 \%$ \\
Yes/No & 13 & $9,29 \%$ \\
\hline Total & 140 & $100 \%$ \\
\hline
\end{tabular}

We can see that most of the pupils said that they were informed about the free time activities organized in the school, $85 \%$ answered the question with "Yes". 
Table 6 shows the structure of the answer to the same question in relation to pupil achievement.

Table 6: Informing pupils about free school activities in relation to school achievement

\begin{tabular}{llll}
\hline Success/claim & Yes & No & Yes/No \\
\hline Excellent (5) & 100 & 0 & 2 \\
Very good (4) & 17 & 4 & 10 \\
Good (3) & 2 & 4 & 1 \\
Enough (2) & 0 & 0 & 0 \\
\hline Total & 119 & 8 & 13 \\
& $85 \%$ & $5,71 \%$ & $9,29 \%$ \\
\hline
\end{tabular}

When the observed features are measured on a nominal scale and in cases where it is possible to form a table for two entrances, which is called the Contingency Table, using the $\mathrm{X} 2$ test, one can get a response to the question asked using the form:

$$
\chi^{2}=\frac{(f i-f i *)^{2}}{f i *}
$$

First, we will formulate a zero and alternative hypothesis:

H0: two characteristics (two variables) are mutually independent,

H1: two characteristics (two variables) are mutually dependent.

In the further procedure we calculate the theoretical frequencies (fi *). The theoretical frequency for the given cell is obtained by dividing the products of columns and rows summations, in which the observed cell is, and the total sum of all frequencies of rows and columns. The further procedure involves calculating the value of $\chi 2$ test statistics.

Table 7: Calculation results of the hi-square test

\begin{tabular}{lllll}
\hline $\mathrm{fi}$ & $\mathrm{fi}^{*}$ & $\mathrm{fi}^{*} \mathrm{fi} *$ & $\left(\mathrm{fi}-\mathrm{fi}^{*}\right)^{2}$ & $\chi^{2}$ \\
\hline 100 & 86.7 & 13.3 & 176,89 & 2,04 \\
17 & 26.35 & -9.35 & 87,42 & 3,32 \\
2 & 5.95 & -3.95 & 15,6 & 2,62 \\
0 & 5.83 & -5.83 & 33,99 & 5,83 \\
4 & 1.77 & 2.23 & 4,97 & 2,81 \\
4 & 0.4 & 3.6 & 12,96 & 32,4 \\
2 & 9.47 & -7.47 & 55,8 & 5,89 \\
10 & 2.88 & 7.12 & 50,69 & 17,6 \\
1 & 0.65 & 0.35 & 0,12 & 0,19 \\
\hline 140 & 140 & 0 & - & 72,7 \\
\hline
\end{tabular}

The calculated value of the $\chi 2$ test statistics is 72.7 . The table value is plotted from the table $\chi^{2}$ with $\mathrm{df}=(\mathrm{r}-1)(\mathrm{c}-1)=(3-1)(3-1)=4$, where $\mathrm{r}$ represents the number of rows and $\mathrm{c}$ the number of columns of the contemplated table and the corresponding level of significance that is common in statistical research $\alpha=$ 0.05 . By comparing the value obtained with the value from the table of $\chi^{2}$ schedule, we arrive at the conclusion that the zero hypothesis is rejected, that is, 
that the two characteristics are mutually dependent, that is, that the obtained answers to the question raised depend on the success of the pupil. Determining the degree of interdependence of two marks of one set, measured on a nominal scale, when their values are only classified by words in different groups, can be determined based on the Pearson Contingency Coefficient:

$$
C=\sqrt{\frac{\chi^{2}}{n+\chi^{2}}}
$$

The coefficient of contingency shows the degree of connection between the modalities of the observed features and takes values from 0 to 1 . If these values are closer to 1 , the relation of the modalities of the observed features is more pronounced. When interpreting the coefficient of contingency, additional information about its maximum value is required:

$$
C_{\text {max }}=\sqrt{(r-1) / r}
$$

It should be noted that it makes no sense to calculate the contingency coefficient when it is determined that the variables are independent of each other.

The resulting value of the coefficient of contingency is 0.58 , while its maximum value is 0.82 , which tells us that there is a high degree of dependence between the two variables.

When asked if there are interesting free time activities organized in your school, $93.58 \%$ of students responded with "Yes", while only one student replied with "No" (0.71\%).

Table 8: Students' interest in free activities

\begin{tabular}{llll}
\hline Success/claim & Yes & No & Yes/No \\
\hline Excellent (5) & 100 & 0 & 2 \\
Very good (4) & 27 & 1 & 3 \\
Good (3) & 4 & 0 & 3 \\
Enough (2) & 0 & 0 & 0 \\
\hline Total & 131 & 1 & 8 \\
& $93,57 \%$ & $0,71 \%$ & $5,72 \%$ \\
\hline
\end{tabular}

Table 8 shows the answers to the question considering pupil achievement. We see that the answers "No" and "Yes / No" are given mostly good and very good pupils.

Using a 5\% risk level, using the $\mathrm{H} 2$ test, it was found that there was a statistically significant difference between the pupil's response and school success. $\chi^{2}=25,16$ and the table value is 9,488 , from which we conclude that the zero hypothesis is rejected, so that the obtained answers depend on the success of the pupils. $\mathrm{Cmax}=0.82$, and the contingency coefficient $\mathrm{C}=0.39$, which means that there is a moderate relationship between the two variables.

Most pupils claim that new free activities have not been introduced in their school recently. The response structure is graphically displayed. 


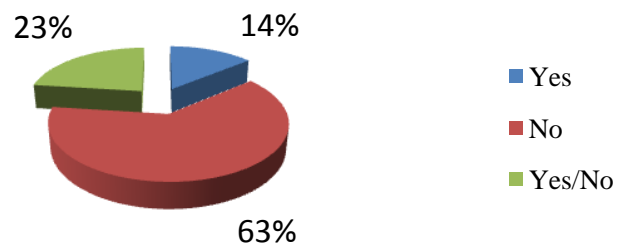

Chart 2: Introduction of new free school activities

Chart 3 shows the data on the grades of free time activities by pupils. In addition to each given free activity, pupils circled the number that best described their answer - (1) - I do not like it at all, (2) - I do not like it, (3) - I like it in part, (4) - I like I, (5) - I really like it.

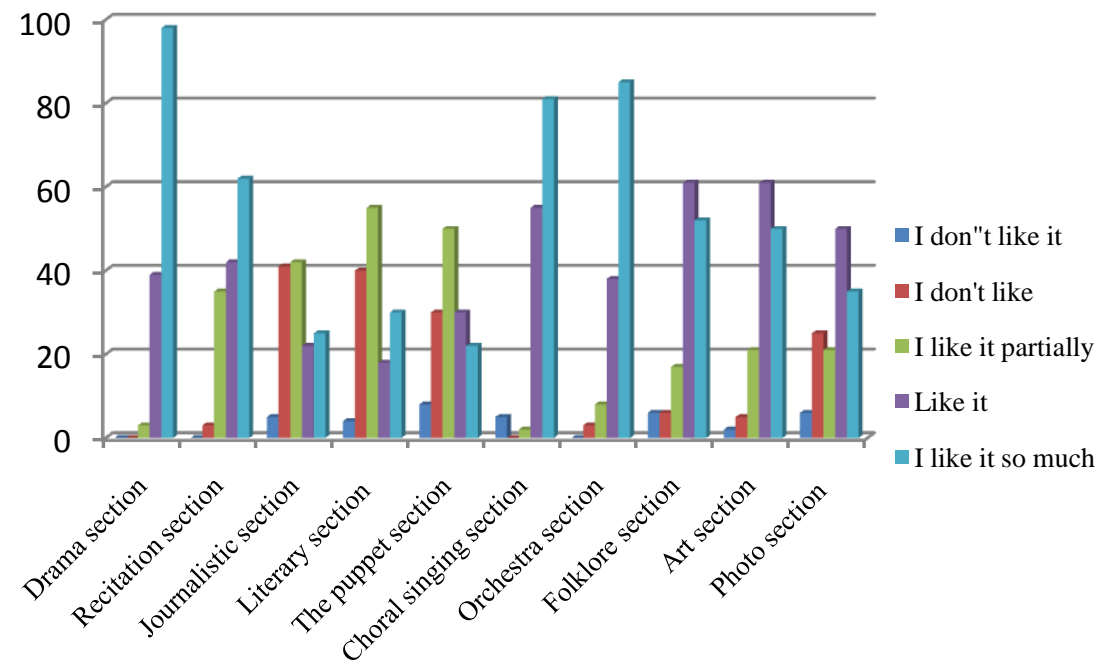

Chart 3: Evaluation of free activities that are in the service of fostering aesthetic taste

By analyzing the obtained data, we can see that the pupils best rated the drama section. Rating (5) I really like it, 98 pupils have circled (70\%), I like it, 39 pupils $(27.86 \%)$ and I partly like it three pupils $(2.14 \%)$. Only for the drama section, no pupil circled the worse grades, or I do not like it and I do not like it very much. The value of $\mathrm{H} 2$ in the evaluation of the drama section is greater than the $\mathrm{H} 2$ limit value at the level of the difference of $5 \%$. This means that the hypothesis is confirmed that there is a statistically significant difference in 
14

interest and the assessment of free time activities given the school's success, gender and school age of pupils.

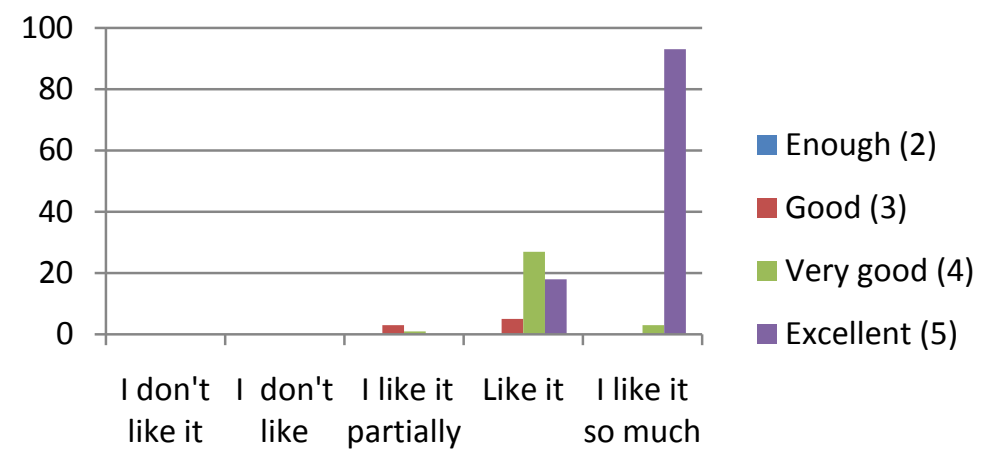

Chart 4: Assessment of the performance of the drama section in relation to student achievement

In Chart 4 and calculating $\chi^{2}=114.3$ of the table value of 15.507 we can see that the obtained answers depend on school success, that is, that excellent students more positively evaluate this free time activity than very good and good students. $\mathrm{Cmax}=0.89$, and the contingency coefficient $\mathrm{C}=0.67$, wich means that there is a strong relationship between the two variables.

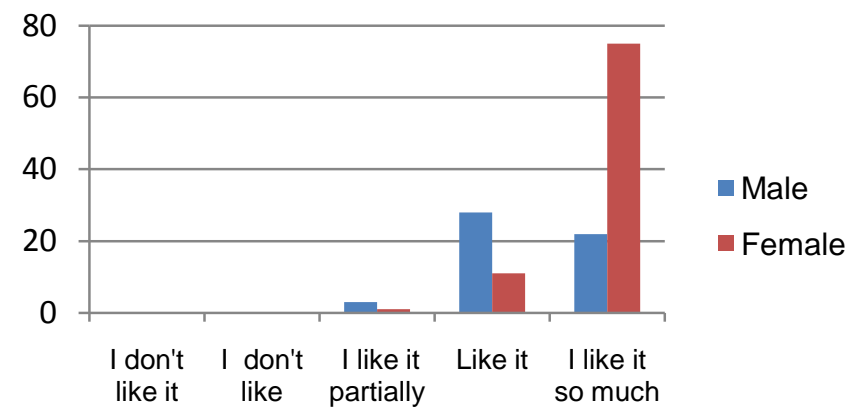

Chart 5. Evaluation of the work of the drama section in relation to the gender of the pupil

The assessment of the drama section in relation to the gender of the pupils is presented in Chart 5, from which we can conclude that girls positively evaluate the work of the drama section in relation to the boys. Although there is a difference in relation to the girls, we see that the boys love the drama section and that they evaluate it positively. 


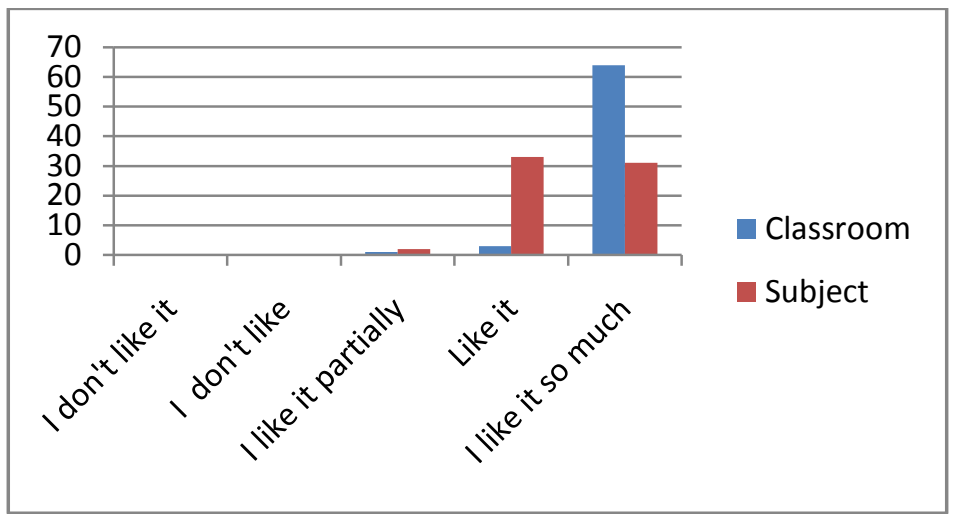

Chart 6: Assessment of the work of the drama section in relation to the school age of the pupils

We can notice that this section is a favourite among students of the junior school age (classroom students), which is also graphically presented.

The grade for the recitation section with regard to gender of pupils is shown in Table 9.

Table 9: Assessment of the recitation section in relation to the half of the students

\begin{tabular}{llllllll}
\hline & \multicolumn{1}{c}{ GENDER } \\
\hline & \multicolumn{1}{l}{ TOTAL } & $\mathrm{M}$ & & $\mathrm{F}$ \\
I don't like it & 1 & 0 & $0.0 \%$ & 0 & $0,0 \%$ & 0 & $0,0 \%$ \\
I don't like & 2 & 2 & $1,43 \%$ & 2 & $3,92 \%$ & 0 & $0,0 \%$ \\
I like it partially & 3 & 31 & $22,14 \%$ & 18 & $35,29 \%$ & 13 & $14,60 \%$ \\
Like it & 4 & 44 & $31,43 \%$ & 20 & $39,22 \%$ & 24 & $26,97 \%$ \\
I like it so much & 5 & 63 & $45,00 \%$ & 11 & $21,57 \%$ & 52 & $58,43 \%$ \\
Table value & & & 9,488 & & & & \\
Hi-square $\chi^{2}$ & & & 21,08 & & & & \\
C $_{\text {max }}$ & & 0,89 & & & & \\
Contigencies C & & 0,36 & & & & \\
\hline
\end{tabular}

The value of $\mathrm{H} 2$ in the questions, in which pupils, with regard to gender, assess whether they like the work of the recitation section is higher than the limit value, with a level of risk of $5 \%$, which means that there is a statistically significant difference in the rating of the recitation section with respect to gender. The drama and recitation sections are more positively rated by the girls. 


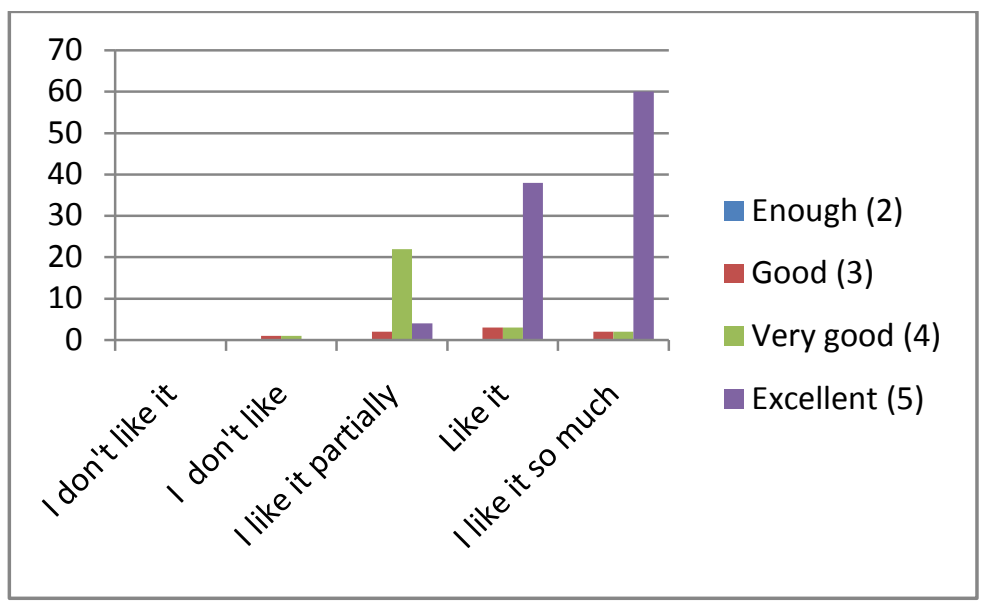

Chart 7: Assessment of the work of the recitation section in relation to student achievement

A statistically significant difference in the rating of the recitation section with regard to the school success and school age of pupils was determined, as shown in Chart 7 and Chart 8. Excellent pupils and students of the junior school age positively evaluate the work of the recitation section in relation to very good and good pupils, and pupils of the older school age.

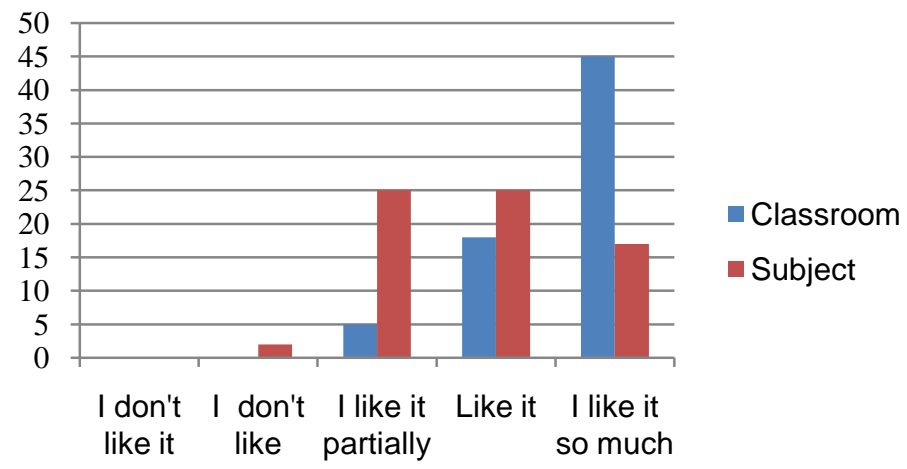

Chart 8: Assessment of the recitation section in relation to the age of students

The journalistic, literary and puppet sections are poorly rated in relation to the drama and recitative, and we assume that these results were not influenced by the organization of their work in schools.

According to the obtained data, the opinion of the pupils on the journalistic section does not depend on gender, and it depends on the school success and the school age, i.e. excellent pupils and pupils of the older school age positively evaluate the journalistic section. 
The literary section is more positively rated by girls, excellent pupils and pupils of older classes, although in the theoretical part we have said that students are less interested in participating in this section, the research showed differently.

According to all the data obtained, where there are statistically significant differences for gender variables, school success and school age, we can conclude that the auxiliary hypothesis about the existence of a statistically significant difference in pupils' interest in participating in free time activities in relation to their socio-pedagogical features is confirmed.

1. The workload of pupils by participating in free time activities

In addition to all the positive characteristics that carry free time activities, the issues of pupils' burden within the sections are also important. Pupils will remain interested in the work of the section, which will contribute to the aesthetic taste enhancement, only if they are not burdened by work in these activities.

When asked Do you think that you have enough free time and that you can take part in some other free time activities that are organized in the school? 124 pupils answered "Yes", 5 pupils answered "No" and 11 pupils "was not sure".

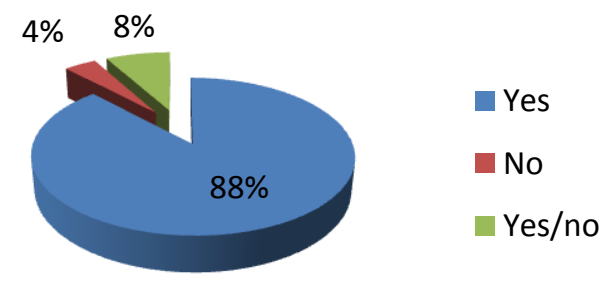

Chart 9: Free time for participation in some other free activities

It was found that there is a statistically significant difference between the pupil's response and school performance using the $\mathrm{H} 2$ test, which is 47.07. Cmax $=0.82$, and the contingency coefficient $\mathrm{C}=0.50$, which means that there is a strong relationship between the two variables. Excellent pupils think they have enough free time and would use it to participate in free time activities.

Table 10: Free time for participation in some other free activities in relation to student achievement

\begin{tabular}{llllll}
\hline Success/claim & Yes & No & Yes/No & Total & $\chi^{2}$ \\
\hline Excellent (5) & 98 & 2 & 2 & 102 & \\
Very good (4) & 25 & 1 & 5 & 31 & \\
Good (3) & 1 & 2 & 4 & 7 & \\
Enough (2) & 0 & 0 & 0 & 0 & \\
\hline Total & 124 & 5 & 11 & 140 & 47,07 \\
& $88,57 \%$ & $3,57 \%$ & $7,86 \%$ & $100,0 \%$ & \\
\hline
\end{tabular}


From the obtained results we can conclude that pupils are not burdened by work in free time activities and given that there is a statistically significant difference between the answers received and the pupils' success, this auxiliary hypothesis has been partially confirmed. With the seventh and eighth questions, we wanted to find out whether the pupils themselves are involved in free time activities or are ordered by teachers.

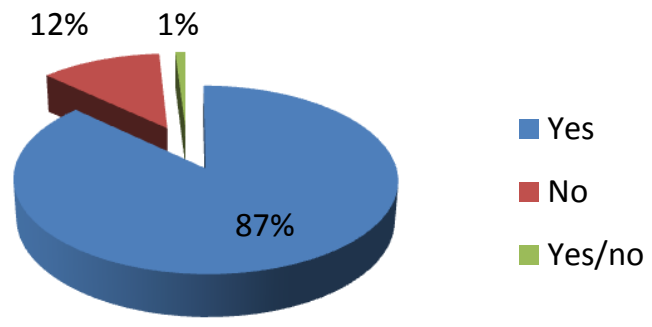

Chart 10: Involving pupils in free activities

In percentage terms, we can conclude that students mostly involve in free time activities on their own, and by calculating the hi-square test we have come to the conclusion that there is no statistically significant difference in answers in terms of gender, school age and school success.

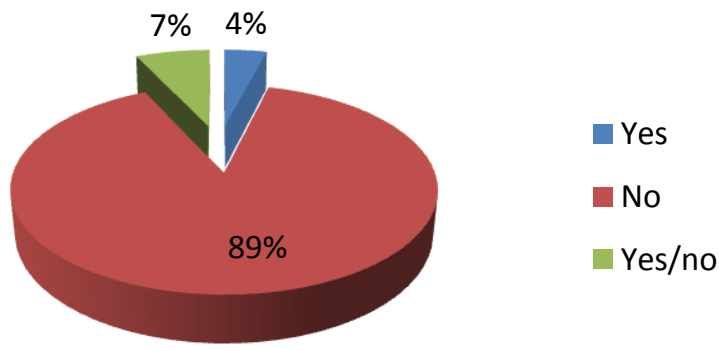
teachers

Chart 11: Involving students in free activities under the influence of

From Chart 11 we see that there is a small percentage of pupils who claim that the teacher ordered them to join the section, but it is not negligible. Incorporating pupils against their will can bring a counter-effect because the pupils ceases to be interested in the activity and begins to hate it.

In order to examine how students see the work of their teachers in working in free time activities, we asked the following question: Are teachers different in working in free time activities than in the regular teaching process? 
Chart 12 shows that $92.86 \%$ of students assert that the work of teachers is different in working in free time activities than in the process of regular teaching, while a small percentage is unsure or think that the work is not different.

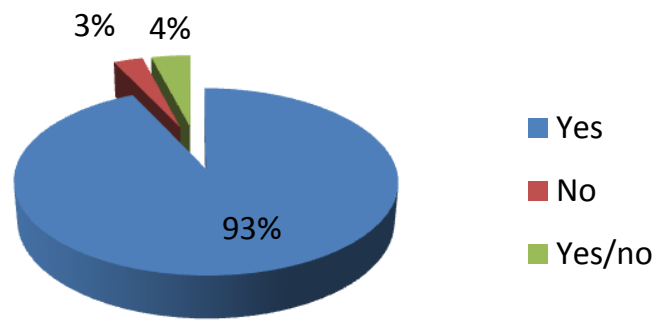

Chart 12: Work of teachers and teachers at work in free activities

We can see that the pupils notice that the work of teachers is different in working in free activities than in the process of regular teaching, and so it should be, because in the theoretical part we already talked about how important it is that the work of teachers differs from that traditional one mainly bound for regular classes. As the name implies, leisure requires a more freer, more open, more accessible role for teachers in these activities than in the regular teaching process.

The tenth question asks for information on whether pupils are absent from regular classes when preparing for a competition, event or public appearance. $75 \%$ of pupils claim that they are not out of school, $20 \%$ claim to be absent while $5 \%$ of pupils did not confirm or deny. The Hi-square test found that there was no statistically significant difference in responses with respect to gender and school age, and that there was a statistically significant difference in relation to school success.

Considering the gender $\chi^{2}=0.536$, and the table value is 5.991, which means that the zero hypothesis is not rejected and that the answers obtained do not depend on pupil's gender. Likewise, considering whether there is a statistically significant difference in responses in relation to school age, we obtained the following data $\chi^{2}=3.81$ and the table value of 5.991, where we can conclude that the obtained answers do not depend on the age of the pupil.

Table 11: Absence of pupils from regular classes due to free activities

\begin{tabular}{llll}
\hline Success/claim & Yes & No & Yes/No \\
\hline Excelent (5) & 26 & 75 & 1 \\
Very good (4) & 2 & 25 & 4 \\
Good (3) & 0 & 5 & 2 \\
Enough (2) & 0 & 0 & 0 \\
\hline Total & 28 & 105 & 7 \\
& $20 \%$ & $75 \%$ & $5 \%$ \\
\hline
\end{tabular}


Regarding very good and good pupils, excellent pupils claim that they sometimes miss out on regular classes because of competitions, performances and public appearances. Because of this difference, we can not say that excellent pupils are burdened with participation in free time activities, but we can say that they are more engaged than very good and good pupils.

On the basis of all the answers received, the other auxiliary hypothesis about the pupils' burden of work in free time activities in relation to gender, school success and school age of pupils is disproved in this case.

1. Opinion of pupils on cultural and artistic events

Cultural and artistic events are the highlight of pupils' work in free time activities. As the event is better, this means that the quality of the activities was greater, and therefore the pedagogical and educational significance as well. This research examines pupils' opinions on cultural and artistic events, as they are intended for them.

Of the total of 140 respondents, 131 had participated in cultural and artistic events (93.57\%), and nine pupils never performed (6.43\%). These are positive results because we see that most students get the opportunity to demonstrate their efforts and work and to affirm, which is the goal of free time activities.

Table 12: Student's views on cultural and artistic events

\begin{tabular}{lll}
\hline Claim & $\mathrm{F}$ & $\%$ \\
\hline They make me happy & 54 & 38,57 \\
I participate in discipline & 6 & 4,29 \\
I'm following them with pleasure & 77 & 55 \\
I can hardly wait for the event to end & 0 & 0,0 \\
Your attitude & 3 & 2,14 \\
\hline Total & 140 & 100,00 \\
\hline
\end{tabular}

We grouped these responses according to the principle positive / negative and obtained the following result: $95 \%$ of the pupils surveyed showed a positive attitude towards school events, and 5\% thought negatively about them. The opinions that the pupils wrote were as follows: I am coming more for socializing, Sometimes they can be interesting, and sometimes very, very boring, everything depends on the participants and I really like to watch it.

Table 13: Students' perceptions of the contents performed at school events

\begin{tabular}{lll}
\hline Claim & F & $\%$ \\
\hline Content is diverse and interesting & 92 & 65,71 \\
Content is uniform and boring & 0 & 0,0 \\
The program is too busy for these events to last long & 0 & 0,0 \\
Content is good, but it is repeated every year & 41 & 29,29 \\
Your opinion & 7 & 5 \\
\hline Total & 140 & 100,00 \\
\hline
\end{tabular}

If all of these responses are grouped according to the same principle, positive / negative, the ratio of $67.86 \%$ positive to $32.14 \%$ of the negative 
opinions about the content that is performed at school events is obtained. The thoughts that the students wrote were as follows: I think they are short, it is better to last longer, Something is interesting, and what I do not like I do not comment but come out of school and wait for the next performance. The content should have more acting and less recitation, Super is funny sometimes, Every year Plavi čuperak, They are good for young children and for the elderly and It's not good that the actors are the same for each performance.

Pupils' opinions on cultural and artistic events are rated positively, but nevertheless a great percentage indicates that something needs to be changed and that pupils do not want to repeat it, it is necessary to listen to the pupils' voice. Teachers should make more effort in choosing content for cultural and artistic events.

Table 14: Structure of the answer to 14. Question regarding school success

\begin{tabular}{llllll}
\hline Success/claim & Yes & No & Yes/No & Total & $\chi 2$ \\
\hline Excellent (5) & 102 & 0 & 0 & 102 & \\
Very good (4) & 29 & 0 & 2 & 31 & \\
Good (3) & 3 & 0 & 4 & 7 & \\
Enough (2) & 0 & 0 & 0 & 0 & \\
\hline Total & 134 & 0 & 6 & 140 & 52,58 \\
& $95,71 \%$ & $0,0 \%$ & $4,29 \%$ & $100,0 \%$ & \\
\hline
\end{tabular}

Pupils were asked whether they consider cultural and artistic events to contribute to their upbringing and development. Based on the data presented in Table 14, using the $\mathrm{H} 2$ test, using a 5\% risk level, we arrive at the conclusion that there is a statistically significant difference between the received responses and pupil achievement. $\mathrm{Cmax}=0.82$, and the contingency coefficient $\mathrm{C}=0.52$, which means that there is a strong connection between the variables. Good and very good pupils have doubts and all excellent students think that cultural and artistic activities contribute to their upbringing and development.

In addition to cultural and artistic performances, visits to cultural institutions and cultural events play a significant role in aesthetic education, and in education in general. We examined how often pupils visit theater, museum, concerts and cinema. The structure of the responses is shown in Table 15.

Table 15: Visit of cultural institutions and cultural manifestations

\begin{tabular}{llll}
\hline Claim & Once a month & Once a year & Never \\
\hline Theter & 0 & 55 & 85 \\
& $0,0 \%$ & $39,29 \%$ & $60,71 \%$ \\
Museum & 0 & 97 & 43 \\
& $0,0 \%$ & $69,29 \%$ & $30,71 \%$ \\
Concert & 0 & 103 & 37 \\
& $0,0 \%$ & $73,57 \%$ & $26,43 \%$ \\
The cinema & 0 & 65 & 75 \\
& $0,0 \%$ & $46,43 \%$ & $53,57 \%$ \\
\hline Average & 0 & 80 & 60 \\
& $0,0 \%$ & $57,14 \%$ & $42,86 \%$ \\
\hline
\end{tabular}


Based on the data we see that the students prefer visiting the concerts $(73.57 \%)$ and they like theatre the least $(39.29 \%)$. It is not surprising that surveyed pupils can not visit a cultural institution or a cultural event once a month considering the environment in which the survey was conducted. This result, taking into account the environment in which the respondents live, is not optimistic, as $42.86 \%$ of children of elementary school never visited the mentioned cultural institutions and manifestations.

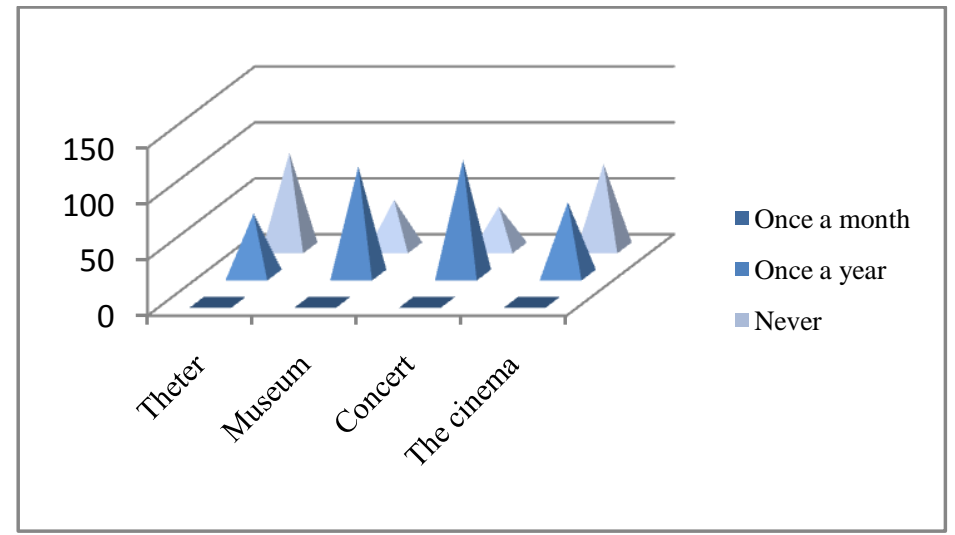

Chart 13: Visit of cultural institutions and cultural manifestations

Going to the theatre should be a holiday for a child. The theater is a synthesis of four media - visual, musical, literary and dramatic. By going to the theatre, children are educated on these four media. The child who visited the theatre will surely want to do it again and will certainly be pleased to be a participant in some free cultural and educational activities in the school.

By analyzing all the data, it is concluded that the main hypothesis has been confirmed. The paper found that free time activities contribute to fostering aesthetic taste and that there is a link between pupil participation in free activities and their sociopedagogical features. The conclusion has appeared, that there are pupils' interests in participating in free time activities, that pupils are optimally burdened and that they are given the opportunity to participate in school events, which confirm that participation in free time activities contributes to the aesthetic taste of pupils.

Auxiliary hypothesis about pupil's interest is confirmed. Pupils are interested in participating in free activities. Girls are more involved in working in free time activities than boys, and excellent pupils in comparison to very good and good pupils. Pupils of both younger and older school age are interested in participating in free time activities organized at school. All pupils are informed about free time activities organized at school. Pupils best rate the drama section. The journalistic, literary and puppet sections are poorly rated in relation to the drama and recitative. Drama, reciter and puppets are more attractive to girls, while the opinion of pupils on the journalistic section does not depend on gender. 
Excellent pupils positively evaluate all free activities of Serbian language and literature.

The research shows that excellent pupils have enough free time and that they can participate in some other free time activities. Pupils are mainly involved in sections with their own will, teachers do not order them. The opinion of pupils about the work of teacher in free time activities is positive. Most pupils think that the work of teachers differs from work in regular classes. According to all the results obtained, we can conclude that the auxiliary hypothesis is disproved. Pupils are optimally burdened and there is no statistically significant difference in responses in relation to socio-pedagogical features.

The analysis of the results led to the conclusion that elementary school pupils have a positive opinion on cultural and artistic events. The opinion of all excellent pupils is that cultural and artistic activities contribute to their upbringing and development, which confirms the main hypothesis.

\section{CONCLUSION}

Aesthetic personality development enriches and broaden aesthetic needs and interests, which encourage pupils to be active, seek to be satisfied and become a powerful motive for the pupil's deeper and more complete involvement in the area of the beautiful. The contemporary school emphasizes the importance of the proper development of aesthetic and creative abilities of pupils in all phases of the age and levels of education and the enrichment of everyday life of pupils to the contents of culture and art. Pupils need to be provided with as many artistic activities as possible for them to build and nurture aesthetic taste.

Free time activities that serve to foster aesthetic taste include all the activities that pupils do in free time, the main goal of which is to broaden and enrich the knowledge of pupils in the field of culture and art. Free time activities are largely represented in schools, and their significance comes to light primarily at elementary school age, because during this period pupils are most interested in different activities. Pupils who are interested in some of the sections voluntarily enroll because it is stipulated by law that free time activities are based on volunteer pronouncement of pupils. In order for pupils to remain interested, activities are performed by the pupils themselves, and teachers are there to encourage, motivate, direct and work together with them. Only interested pupils can achieve the goal of cultural and artistic activities, and their main goal is to become a permanent pupil culture.

These activities should not burden pupils in any way. They should not become mandatory for pupils, nor should they be given time in regular classes. The burden for pupils can also be that teachers sometimes do not take sufficient care of the age of pupils, so the free time activities treat everyone in the same way at different ages. Teachers should gradually introduce students to free time activities. The organization and working method of the section allows students to 
satisfy their interests. When establishing certain types of free time activities, the choice of content and methods of work, it is necessary to take into account compliance with the overall goal and tasks of education in school and society, about the abilities and needs of children, and above all, the expertise and professionalism of teachers.

Analyzing and interpreting the results lead to the conclusion that schools offer pupils those activities for which they have conditions. There are no journalistic and puppet sections in the schools where the research was conducted, because there are no conditions for their organization. Regarding the correlation between pupil participation in free time activities and their socio-pedagogical features, we can say that the difference exists in relation to gender and school success, whereas in relation to the school age there is no. difference. Girls are more involved in working in free time activities than boys, and excellent pupils in relation to very good and good. Pupils of both younger and older school age are interested in participating in free time activities. Given that pupils were informed about free time school activities, and that 93.57 pupils answered that they had interesting free time activities organized at school, we can conclude that we have achieved positive results and that pupils are interested in the working in free time activities. Pupil's interest was also confirmed by the positive evaluation of cultural and artistic activities. The pupils best rated the drama section.

Pupils in elementary school are interested in more things at once. Free time activities are there to focus all their attention on the area that suits them best. The research shows that excellent pupils have enough free time and that they can participate in some other free activities. Pupils are mainly involved in sections on their own, teachers do not order them. Excellent students (20\%) claim that they sometimes miss out on regular classes due to performances, public appearances or competitions. This practice of teachers preparing for an event or competition at the expense of teaching can cause overburdening of pupils by working in free time activities. Teachers of free activities are expected to have primarily a different approach to that involved in traditional teaching. He must be the driving force of activity, to be a diagnostician who reveals the strongest pupil's ability and focuses on it, advises students, and likes to experiment. Precisely because of the different roles of teachers, we examined the pupil's opinion on whether there are differences between their role at work in free activities in relation to the work in the regular teaching process. The student's opinion is positive, the majority of students believe that the work of teachers in free time activities differs in relation to the work in regular classes. According to all the data obtained, the auxiliary hypothesis that the pupils are overloaded with work in free time activities and that there is a statistically significant difference in answers in relation to their gender, school age and school success is denied, which is quite positive.

Elementary school pupils have a positive opinion about the cultural and artistic events and the contents that are being performed on them. Data analysis has shown that cultural and artistic events are a joy for students and that they are followed with pleasure, but that they do not want to repeat the content on them. 
The opinion of all the excellent pupils is that cultural and artistic activities contribute to their upbringing and development, and from this and all of the above, we can conclude that the pupils are promoting the cultivation of aesthetic taste. The link between school success and participation in free time activities is that the success that pupils achieve in free time activities encourages further activity that contributes to better success in the field of teaching. Whether a person will develop aesthetic taste depends on whether a certain educational influence has been directed to it during the critical period of its growing up. It is precisely the great importance of the school because it has educational opportunities in all segments. We hope that this research will help some future researchers in this field, but also teachers who can apply these results in practice.

\section{REFERENCES}

Babin, R. (1986). Tematsko-idejni profil školskih priredbi. Pedagoška stvarnost, 32(9/10), 758-762.

Bećar, J. (1986). Struktura slobodnih aktivnosti u starijim razredima osnovne škole. Pedagoška stvarnost, 32(9/10), 776-781.

Branković, D., \& Ilić, M. (2003). Osnovi pedagogije. Banja Luka: Comesgrafika.

Grandić, R., \& Letić, M. (2008). Prilozi Pedagogiji slobodnog vremena. Novi Sad: Savez pedagoških društava Vojvodine; Vršac: Visoka škola strukovnih studija za obrazovanje vaspitača "Mihailo Palov".

Đorđević, M. (1985). Individualizacija obrazovnog rada u školi. Beograd: Nova prosveta.

Pjurkovska-Petrović, K., \& Ševkušić, S. (1997). Slobodne aktivnosti učenika - rad sekcija u osnovnim školama. Nastava $i$ vaspitanje, 46(2/3), 350361.

Potkonjak, N., \& Šimleša, P. (1989). Pedagoška enciklopedija 2. M-Ž. Beograd: Zavod za udžbenike i nastavna sredstva.

. Official Gazette of the Republic of Srpska, (2008). 74/08,

. Official Gazette of the Republic of Srpska, (2011). 51/11,

Cvetković, B. (1999). Vannastavne obrazovno-vaspitne aktivnosti u mlađim razredima osnovne škole. Nastava $i$ vaspitanje, 48(3/4), 395-408.

Panić, D. S., Lazić, D. D. \& Mitrović, L. L.. (2017). Pedagogical communication: Achievement and frequency in general class teaching. Sintezečasopis za pedagoške nauke, književnost i kulturu, 11, 1-38. doi:10.5937/sinteze614011 
ОБЛИЦИ СЛОБОДНИХ АКТИВНОСТИ УЧЕНИКА У СЛУЖБИ ЊЕГОВАҢА ЕСТЕТСКОГ УКУСА

Љиљана Љ. Митровић $\hbar^{1}$, Данијела С. Панић², Драгана Д. Лазић

Сажетак: Овај рад се бави слободним активностима ученика, односно, организованим облицима васпитно-образовног рада који се остварује кроз рад секција које су у служби његовања естетског укуса. У раду је испитано мишљење ученика о учешћу у секцијама. Узорак овог истраживања је чинило 140 ученика из четири основне школе. Истраживање је вршено методом прикупљања података и техником анкетирања, а као инструмент је кориштен упитник. Резултати истраживања показују да су ученици заинтересовани за рад у слободним активностима, да нису преоптерећени радом у њима и да имају позитивно мишљење о културноумјетничким приредбама. Такође, резултати показују повезаност школског успјеха ученика и учешћа у слободним активностима. Рад доноси корисна знања о интересовањима ученика.

Кључне ријечи: слободне активности, секције, основна школа, естетски укус, културно-умјетничке приредбе

Примљен: 29.03.2018.

Прихваћен: 02.07.2018.

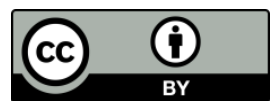

\footnotetext{
${ }^{1}$ mitroviclj@spinter.net, ОШ "Вук Караџић" Забрђе, БиХ

${ }^{2}$ simeunovic.danijela@gmail.com, ОШ „Кнез Иво од Семберије", Бијељина, Република Српска, БиХ

3 draganaldj@gmail.com, ОШ „Кнез Иво од Семберије", Бијељина, Република Српска, БиХ
} 